\title{
Galleys as a Total Institution
}

\section{Galery jako instytucja totalna}

\author{
Andrzej Borowski \\ Department of Sociology and Social Works, Faculty of Education and Philosophy, \\ Pomeranian University in Słupsk, 64 Westerplatte St., 76-200 Słupsk, Poland \\ E-mail address: aubor@poczta.onet.pl
}

\begin{abstract}
Galleys as the closed/total institution/, is regarding the whereabouts of the certain number of people isolated for a long stretch from the rest of society, remaining in the similar situation, of which the behaviour is under almost the total control of the staff of this institution. In the period of the antiquity slaves were the basic driving force of galleys but their fate resulted from the social status. In the period of the Middle Ages, galley slaves, called in Italian galeotti, they were free people, and their profession enjoyed the respect. Above all in France they have more and more often started with the 15th century to use galleys as the place of serving a penalty of imprisonment. This situation lasted to the mass scale till the XVIII century second-half, leaving in the social awareness stereotype of the galley slave.
\end{abstract}

Keywords: total institutions; gallery; ship; punishment; prison

\section{STRESZCZENIE}

Galery jako instytucja zamknięta/totalna/, dotyczy miejsca pobytu pewnej liczby osób odizolowanych na dłuższy okres od reszty społeczeństwa, pozostających w podobnym położeniu, których zachowanie jest pod prawie całkowitą kontrolą personelu tej instytucji. W okresie starożytności podstawową siłą napędową galer byli niewolnicy lecz ich los wynikał ze statusu społecznego. W okresie średniowiecza, galernicy, zwani po włosku galeotti, byli ludźmi wolnymi, a ich zawód cieszył się poważaniem. Od XV wieku przede wszystkim we Francji coraz częściej zaczęto wykorzystywać galery jako miejsce odbywania kary pozbawienia wolności. Sytuacja taka trwała na skalę masową do drugiej połowy XVIIIw. pozostawiając $\mathrm{w}$ świadomości społecznej stereotyp galernika.

Słowa kluczowe: instytucje totalne, gallery, statek, kara, więzienie 


\section{WPROWADZENIE}

W socjologicznym rozumieniu pojęcie galer jako instytucji zamkniętej/ totalnej/, dotyczy miejsca pobytu pewnej liczby osób odizolowanych na dłuższy okres od reszty społeczeństwa, pozostających w podobnym położeniu, których zachowanie jest pod prawie całkowitą kontrolą personelu tej instytucji Pobyt na galearach wiąże sie zazwyczaj z odbywaniem specyficznej formy kary pozbawienia wolności.

Według E. Goffmana, autora tego pojęcia, w społeczeństwie występują rozmaite instytucje totalne które można podzielić na kilka grup z których jedna w szczególny sposób dotyczy takich miejsc w których totalność ma charakter instumentalny i służy optymalizacji działania [1,5-7].

W rzeczywistości społecznej zaliczyć do tej sfery można między innymi instytucje takie jak koszary wojskowe i policyjne, internaty szkolne, i campusy akademickie, statki morskie, osiedla popegeerowskie, naukowe stacje badawcze, platformy wiertnicze, kopalnie. Istnieją też hybrydowe formy instytucji totalnych będące połączeniem niektórych z nich. Przykładem mogą być takie miejsca jak akademie wojskowe i policyjne - połączenie koszar i campusu akademickiego, okręty - połączenie koszar i statków, statki i stacje kosmiczne - połączenie stacji badawczych i statków morskich, poruszających się w przestrzeni kosmicznej oraz galery - połączenie statków morskich i więzienia.

Osoby przebywające w instytucjach totalnych niezależnie od własnych umiejętności bądź określonych zadań mają do pokonania w zależności od rodzaju i typu instytucji od kilku do kilkunastu dodatkowych barier [2].

Podstawowe bariery występujące w tej kategorii instytucji totalnych można podzielić na:

A) Bariery fizyczne:

a) naturalne:

- lądolód, pustynia, las, wysokie góry

- woda

- głębia morska, ziemia

- przestrzeń kosmiczna

b) sztuczne:

- zasieki z drutu kolczastego, siatka, uniform, obroża

- krata, żywopłot, płot,

- drzwi, mur, most zwodzony [3].

B) Bariery symboliczne:

a) regulamin pobytu, żargon

b) ostracyzm, stygmatyzacja, izolacja psychiczna /wyuczona bezradność/

c) izolacja medyczna /kwarantanna/, izolacja prawna /zakaz wstępu/, izolacja społeczna /brak łączności i dostępu do informacji z zewnątrz/ [4].

\section{REKRUTACJA GALERNIKÓW}

W okresie starożytności podstawową siłą napędową galer byli niewolnicy lecz ich los wynikał ze statusu społecznego. W okresie średniowiecza, galernicy, zwani po włosku galeotti, byli ludźmi wolnymi, a ich zawód cieszył się poważaniem. Jednak od XV wieku sytuacja uległa zmianie. Część wioślarzy, określanych mianem „turków”, kupowano od imperium osmańskiego. Większość z nich była muzułmanami, choć niektórzy wyznawali prawosławie. 
Na galery zabierano również jeńców wojennych. Osobnym rozdziałem jest funkcjonowanie tej instytucji w Królestwie Francji. Wiązalo się to zwłaszcza z realizacją w XVIIw. planów Ludwika XIII i Ludwika XIV które zakładały rozbudowę floty dzięki dużej ilości wioślarzy. Minister finansów Francji J. B. Colbert znalazł stosowne rozwiązanie, nakłaniając sędziów iż zgodnie z życzeniem króla powinni: „wydawać jak najwięcej wyroków skazujących i nawet karę śmierci powinni zamieniać na galery”.

Wykorzystanie przestępców jako siły napędowej statków nie było niczym nowym. Na galerach pracowali oni już jakieś dwa stulecia wcześniej, podczas wojen z Włochami. Za panowania Ludwika XIV i jego potomków, na galery skazano niespotykaną wcześniej w całej Europie liczbę osób. Przykładowo w latach 1680-1748 los ten podzieliło około 60000 mężczyzn. Na rysunku 1, przedstawiono wykorzystywanie przestępców jako siły napędowej statków.

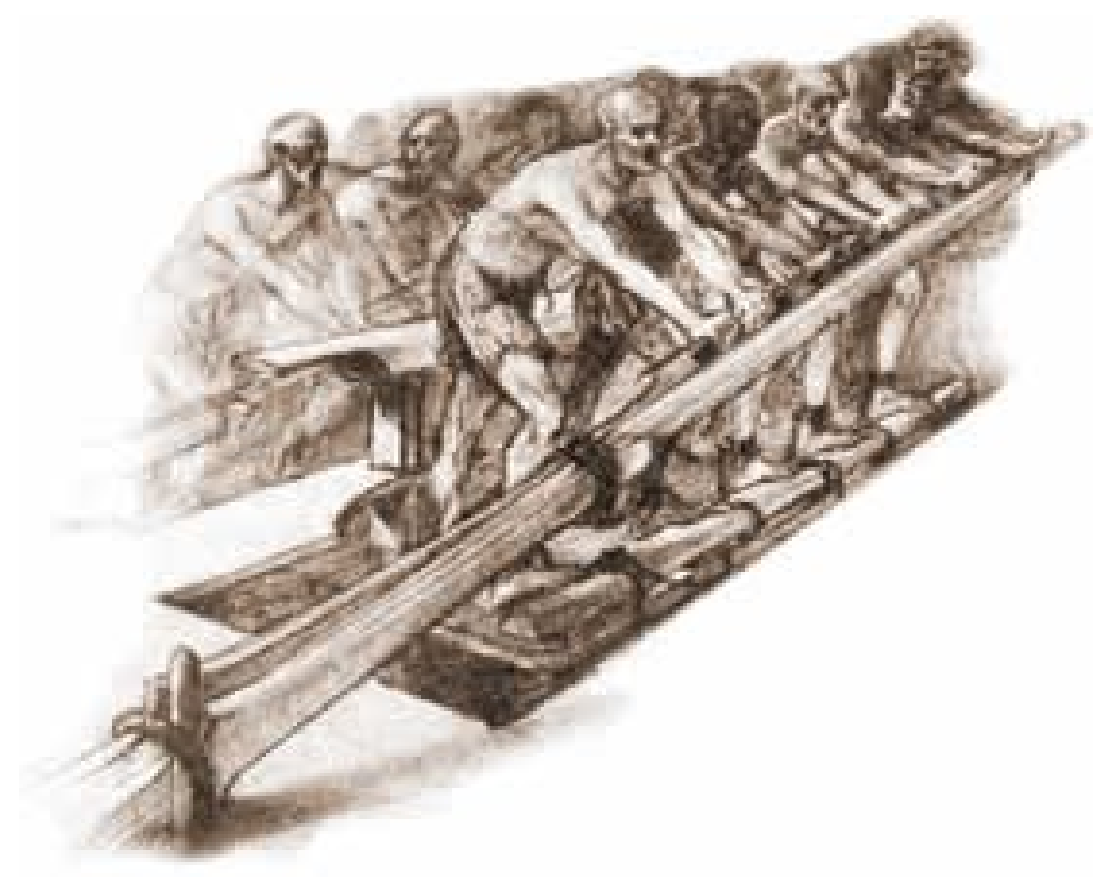

Rys. 1. Wykorzystanie przestępców jako siły napędowej statków.

Znaczną część galerników stanowili pospolici przestępcy - od zabójców po drobnych złodziei. Do pracy na galerach zmuszano również ludzi z marginesu społecznego w ramach polityki wielkiego zamknięcia jako alternatuwa pobytu w tzw Szpitalach Generalnych. Pod pretekstem dbałości o porządek publiczny, na galery posyłano także Cyganów i biedaków. Na dożywotnią karę galer skazywano również dezerterów. Okaleczano ich i znakowano godłem królewskim.

Bycie galernikiem zaczynało się jeszcze przed wyruszeniem na morze. Przez czas około pól roku trzymano ich $\mathrm{w}$ tymczasowych mirejsca odosobnienia, by później wraz $\mathrm{z}$ innymi skutych łańcuchami pędzono do portu w Marsylii. Dla skazańców z północnych prowincji Francji taki przymusowy kilklusetkilometrowy marsz był dodatkową udręką, trwającą czasem nawet miesiąc. 
Po przybyciu do portu samo wcielenie do społeczności galerników powodowało uczucie skrajnego zagubienia oraz było ogromnym szokiem zarówno psychicznym jak i fizycznym. Pracę galerników można porównać do najcięższych robót, wykonywanych w klimacie tropikalnym. Większość galer miała niskie burty, a wioślarze znajdowali się zaledwie około metra powyżej linii wodnej. W rezultacie wciąż byli przemoczeni, ich stopy stały w wodzie, a W skórę wżerała się sól morska. Ucieczka praktycznie nie była możliwa.

Rzadko kiedy personel galer respektował zasądzone wyroki. Osoby mające odbyć kilkuletnią karę, nawet po upływie kilkukrotnie dłuższego okresu wciąż pracowały na galerach. Osobną kategorię galerników stanowili heretycy wynikało to z uchylenia Edyktu nantejskiego i zabroninienia praktykowania protestantyzmu. Około 1500 protestantów, którzy odmówili przejścia na katolicyzm lub próbowali uciec z Francji, zostało skazanych na galery. Karę galer wymierzono również wcześniej w roku 1545, kiedy to na rozkaz króla Franciszka I w ciągu jednego tygodnia zesłano na galery 600 waldensów. Za panowania Ludwika XIV, który uchodził za bardzo chrześcijańskiego króla, prześladowania te przybrały nowy wymiar.

Król zakładał, że większość skazanych protestantów, porzuci religię, lecz tylko nieliczni wyrzekli się wiary w zamian za wolność. Dlatego, publicznie wymierzano im chłostę. Takie traktowanie nie powstrzymywało jednak protestanckich galerników od niesienia pomocy a nawet oraganizowali naukę czytania i pisania dla towarzyszy którzy byli analfabetami. Dopiero w roku 1713, dzięki zabiegom angielskiej królowej, zwolniono większość protestanckich galerników, połączono to jednak z banicją.

\section{LIKWIDACJA GALER}

Ostatecznie galery stały się ofiarą postępu w żegludze i braku finansowych.W roku 1720 pozostało już tylko 15 statków i korzystano z nich bardzo rzadko. Przez większość czasu galernicy przebywali w Marsylii i brali udział w życiu ekonomicznym miasta pracując w fabrykach lub sprzedając własnoręcznie robione ubrania. W roku 1748 uchwalono prawo, które w gruncie rzeczy okazało się pratycznym kresem funkcjonowania galer. Niemniej sama kara i obraz galernika wrył się głęboko w świadomość nie tylko Francuzów ale i innych nacji na europejskim kontynencie. Galernikami w pewnym okresie stali się nawet przedstawiciele północnoamerykańskiego plemienia Irokezów jako kara za bunty przeciwko francuskiej kolonizacji ich własnych terenów.

W literaturze znaczący wkład w budowanie wizji rzeczywistości galer wniósł V. Hugo poprzez powieść „Nędznicy”. Większość galerników umierało w okresie pierwszych trzech lat. Inni czasem wyrzekali się wiary w zamian za obietnicę wyzwolenia. Ostatnim protestantem skazanym na galery był niejaki Jan Viala, który w 1762 r. otrzymał wyrok skazujący na 6 lat galer. Zmarł jednak w 1764 r. Natomiast ostatni dwaj protestanci - 77-letni krawiec Antoni Raille i 64-letni szewc Paweł Achard - odzyskali wolność na mocy aktu łaski 30 IX 1775 roku... po 30 latach odbywania kary (od 1745 r.).

\section{WNIOSKI}

Do chwili obecnej w świadomości społecznej funkcjonuje stereotyp galer i osoby galernika jako jednej z najcięższych w historii ludzkości formy odbywania kary pozbawienia wolności. Zamknięcie rozdziału w historii wykonywania tej kary związanego z galerami wiązało się z ogólną ewolucją systemu penitencjarnego w końcu XVIII jako wyniku rozważań 
oświeceniowych myślicieli i polityków, w kierunku funkcjonowania instytucji penitencjarnych jako narzędzia resocjalizacji a nie społecznej zemsty na sprawcach.

\section{References}

[1] K. Olechnicki, P. Załęcki, Słownik socjologiczny, Toruń, 1997, s. 85.

[2] A. Borowski, International Letters of Social and Humanistic Sciences 2 (2013) 56-60.

[3] A. Borowski, International Letters of Social and Humanistic Sciences 3 (2013) 69-74

[4] A. Borowski, International Letters of Social and Humanistic Sciences 4 (2013) 70-74.

[5] Benny Goodman, Nurse Education Today 33(2) (2013) 81-82.

[6] Catrin Johansson, Public Relations Review 33(3) (2007) 275-280.

[7] Robert White, Dallas Hanson, Scandinavian Journal of Management 18(3) (2002) 285-301. 